\title{
De ontwikkeling van een Euregionaal informatiesysteem onderwijs-arbeidsmarkt voor de Euregio Maas-Rijn
}

Citation for published version (APA):

Teunis, U. (1996). De ontwikkeling van een Euregionaal informatiesysteem onderwijs-arbeidsmarkt voor de Euregio Maas-Rijn. Researchcentrum voor Onderwijs en Arbeidsmarkt, Faculteit der Economische Wetenschappen. ROA Working Papers No. 7 https://doi.org/10.26481/umarow.1996007

Document status and date:

Published: 01/01/1996

DOI:

10.26481/umarow. 1996007

Document Version:

Publisher's PDF, also known as Version of record

Please check the document version of this publication:

- A submitted manuscript is the version of the article upon submission and before peer-review. There can be important differences between the submitted version and the official published version of record.

People interested in the research are advised to contact the author for the final version of the publication, or visit the DOI to the publisher's website.

- The final author version and the galley proof are versions of the publication after peer review.

- The final published version features the final layout of the paper including the volume, issue and page numbers.

Link to publication

\footnotetext{
General rights rights.

- You may freely distribute the URL identifying the publication in the public portal. please follow below link for the End User Agreement:

www.umlib.nl/taverne-license

Take down policy

If you believe that this document breaches copyright please contact us at:

repository@maastrichtuniversity.nl

providing details and we will investigate your claim.
}

Copyright and moral rights for the publications made accessible in the public portal are retained by the authors and/or other copyright owners and it is a condition of accessing publications that users recognise and abide by the legal requirements associated with these

- Users may download and print one copy of any publication from the public portal for the purpose of private study or research.

- You may not further distribute the material or use it for any profit-making activity or commercial gain

If the publication is distributed under the terms of Article $25 \mathrm{fa}$ of the Dutch Copyright Act, indicated by the "Taverne" license above, 
De ontwikkeling van een Euregionaal informatiesysteem onderwijsarbeidsmarkt voor de Euregio Maas-Rijn

ROA-W-1996/7

U. Teunis

Researchcentrum voor Onderwijs en Arbeidsmarkt

Faculteit der Economische Wetenschappen en Bedrijfskunde Universiteit Maastricht

Maastricht, december 1996 
ISBN 90-5321-200-0 
Inhoud

Bladzijde

Voorwoord

1 Werkwijze en uitkomsten 1

1.1 Voorgeschiedenis, doelstelling

1

1.2 De uitvoering van het projectplan in hoofdlijnen

3

2 Uitkomsten in hoofdlijnen

3 Overdraagbare uitkomsten en conclusies 


\section{Voorwoord}

Het project 'ontwikkeling informatiesysteem onderwijs - arbeidsmarkt ten behoeve van de Euregio Maas - Rijn' heeft geresulteerd in een eerste editie van het 'Overzicht onderwijsarbeidsmarkt Euregio Maas - Rijn (ROA-R-1996/13). Naast dit concrete informatieproduct brengt het ROA het navolgende werkdocument uit, dat in de eerste plaats is bestemd voor de opdrachtgever, het ministerie van Onderwijs, Cultuur en Wetenschappen, directie Beroepsonderwijs en Volwasseneneducatie BVE. Dit geschiedt om twee redenen. Ten eerste zijn de in een onderzoeksrapport gebruikelijke elementen van verantwoording van werkwijze en uitkomsten niet opgenomen in het Euregionaal Overzicht; dit is immers bedoeld als informatieproduct ten behoeve van betrokkenen binnen en buiten de Euregio. Ten tweede is in overleg met de opdrachtgever (zie paragraaf 2.2) afgesproken dat in de rapportage aandacht zou worden besteed aan leerervaringen die van belang kunnen zijn voor vergelijkbare projecten in andere Euregio's. Ook dit element van overdraagbare kennis komt niet tot uitdrukking in het Euregionaal Overzicht.

In dit werkdocument wordt eerst ingegaan op de voorgeschiedenis van het project en op de doelen en werkwijzen, omschreven in de goedgekeurde offerte (projectplan). Vervolgens wordt ingegaan op de wijze van uitvoering, in de vorm van een globaal procedureel verslag (hoofdstuk 1). In hoofdstuk 2 volgt een analyse van de mate waarin de doelstellingen van het project zijn gerealiseerd en van de mogelijke oorzaken van het al dan niet realiseren van bepaalde onderdelen. Dit geschiedt aan de hand van de vier in het projectplan omschreven deelprojecten. In hoofdstuk 3 tot slot wordt nader ingegaan op enige specifieke thema's die van belang kunnen zijn voor de overdracht van ervaringen naar vergelijkbare projecten in andere Euregio's. Aan deze thematische verdieping wordt een aantal conclusies en aanbevelingen verbonden.

Het project is voor wat betreft de hoofdlijnen en de contacten met betrokken organisaties in de Euregio uitgevoerd door drs. U. Teunis, in het kader van het tweede jaar van zijn Interim Functievervulling vanuit het ministerie van OCW, J. van Loo heeft als student-assistent een belangrijk aandeel gehad in de dataverzameling en -bewerking en in de voorbereiding van het Overzicht. De leiding van het project als geheel berustte bij dr. A. de Grip; dr. R.K.W. van der Velden heeft de begeleiding van het onderdeel 'betrokkenheid onderwijsinstellingen' verzorgd. Specifieke bijdragen aan de dataverzameling hebben verder drs. J. Horbeek en drs. A. Matheeuwsen geleverd. 



\section{Werkwijze en uitkomsten}

\subsection{Voorgeschiedenis, doelstelling}

Het project 'Ontwikkeling informatiesysteem onderwijs - arbeidsmarkt ten behoeve van de Euregio Maas - Rijn' vloeit voort uit de, eveneens door het ROA uitgevoerde, verkennende studie 'Informatiesysteem onderwijs - Arbeidsmarkt voor de Euregio Maas - Rijn'1. In deze verkennende studie lag de nadruk op vragen betreffende enerzijds de mogelijke behoeften aan Euregionale arbeidsmarktinformatie bij diverse instanties binnen de Euregio, anderzijds de mogelijkheden tot realisatie van een dergelijk systeem in verband met de beschikbaarheid van gegevens.

Op beide vragen werd een in hoofdlijn positief antwoord gegeven. Bij diverse instanties werd belangstelling aangetroffen, in een aantal gevallen naast een meer of minder actieve verzameling en benutting van reeds aanwezige gegevens. Wat betreft de beschikbaarheid van gegevens was de conclusie dat de meeste onderdelen van een denkbaar informatiesysteem zouden kunnen worden gevuld, zij het niet voor ieder deel van de Euregio volledig en niet volledig vergelijkbaar. Hieraan werd de aanbeveling verbonden een informatiesysteem zoveel mogelijk voor en in samenwerking met relevante instanties binnen de Euregio te ontwikkelen, niet alleen met het oog op de beschikbaarheid van gegevens maar vooral met het oog op actief gebruik en actieve voortzetting van het informatiesysteem.

Het rapport van de verkennende studie is als concept verspreid in februari 1995. In druk kwam het beschikbaar in mei 1995. In mei en juni is het op ruime schaal verspreid richting instellingen en instanties binnen de Euregio, mede met het oog op mogelijke betrokkenheid bij de verdere ontwikkeling van een Euregionaal Overzicht.

Met een mogelijke voortzetting van het Euregio-project was bij de uitvoering van de verkennende studie geen rekening gehouden. In het rapport werd ervan uitgegaan dat de betrokken instellingen zelf, gezien hun belangstelling voor en belang bij een informatiesysteem, de ontwikkeling ter hand zouden kunnen nemen. Wel zou een duidelijke initiatief- en coördinatiefunctie dienen te worden belegd. Hiervoor werden geen nadere aanbevelingen gedaan.

In maart 1995 vond, op basis van het rapport van de verkennende studie, overleg met de opdrachtgever plaats, in persoon van de heren Van den Dooi en Verlaan. In dit gesprek bleek de bereidheid tot ondersteuning van een eerste aanzet tot ontwikkeling van het informatiesysteem. De overweging vanuit BVE was daarbij dat de ontwikkelingen binnen de Euregio's mede als een belangrijke 'proeftuin' kunnen worden gezien voor internationalise-

1. U. Teunis, Informatiesysteem onderwijs-arbeidsmarkt voor de Euregio Maas-Rijn, ROA-R1995/2, Maastricht, 1995. 
ringstendensen in het algemeen. Op basis hiervan is een projectvoorstel ingediend, dat de grondslag vormde voor aanbesteding van dit project.

Het projectplan

Het projectvoorstel gaat uit van de aanbeveling uit het rapport van de verkennende studie, het informatiesysteem zoveel mogelijk 'van, voor en door' de betrokken instellingen in de Euregio te ontwikkelen. Inzet is daarbij niet alleen de beschikbaarstelling van aanwezige gegevens maar ook de betrokkenheid bij en medeverantwoordelijkheid voor het systeem; als uitgangspunt werd immers de ontwikkeling van een op termijn zelffinancierend systeem gezien. Meer dan in het rapport wordt in het projectvoorstel echter het belang onderkend dat zeker in de fase van eerste ontwikkeling van het systeem een herkenbare 'drager' naar voren treedt die het initiatief neemt en een spilfunctie vervult in het ontwikkelingsproces. De verwachting wordt uitgesproken dat in eerste instantie van de betrokken instellingen in de meeste gevallen vooral passieve medewerking te verwachten is. Geen van deze instellingen zal de ontwikkeling van het systeem tot haar kerntaak rekenen als 'drager' naar voren treden. De overkoepelende organen binnen de Euregio, met name de Stichting Euregio Maas - Rijn en het EURES-CROSSBORDER project binnen de Euregio hebben daartoe onvoldoende middelen.

In het projectvoorstel wordt daarom voorgesteld dat in de eerste ontwikkelingsfase van het informatiesysteem het ROA zelf als 'drager' op zal treden. Het ROA werkt in die fase samen met een aantal instellingen dat bereid blijkt tot een actieve bijdrage; met anderen wordt een meer passieve relatie opgebouwd, gericht op de eventuele levering van gegevens en op afname en gebruik van de producten. Het actieve samenwerkingsverband zou ook moeten streven naar subsidiëring uit Europese fondsen, als grondslag voor verdere ontwikkeling. Daarbij werd met name aan INTERREG-II gedacht.

Aansluitend op de in het rapport van de verkennende studie aanbevolen activiteiten werd voorgesteld dat het project vier deelprojecten zou omvatten:

1. Ontwikkeling van een Euregionaal Overzicht onderwijs - arbeidsmarkt op basis van aanwezige gegevens en publicaties. Dit deelproject zou moeten resulteren in een eerste daadwerkelijke publicatie van een eerste versie van het Euregionaal Overzicht.

2. Ontwikkeling van kwalitatieve signalementen op basis van reeds lopende projecten binnen de Euregio.

3. Betrokkenheid van het onderwijs, ontwikkeling Euregionaal Overzicht opleidingen. Hierbij werd gedacht aan de opbouw van relaties met onderwijsinstellingen als mogelijk informatievragende partij en aan de opbouw van een informatiesysteem betreffende onderwijsvoorzieningen op Euregionale schaal.

4. Initiatief, coördinatie en continuïteit: het geheel aan activiteiten gericht op het 'dragerschap' binnen het project en de verdere inbedding van het ontwikkelde informatiesysteem binnen de Euregio. 
Van twee in het rapport van de verkennende studie voorgestelde activiteiten werd vastgesteld dat deze in een later stadium of in ander verband tot stand zouden moeten worden gebracht: de opzet van schoolverlatersonderzoek betreffende de aansluiting tussen onderwijs en arbeidsmarkt in alle Euregio-delen en de ontwikkeling van arbeidsmarktprognoses voor de Euregionale arbeidsmarkt.

Het projectvoorstel werd vrijwel integraal opgenomen in een projectplan, dat binnen de Euregio is verspreid en dat als grondslag heeft gediend voor overleg met diverse instellingen en instanties en dat zo een belangrijke rol heeft gespeeld in de opbouw van een samenwerkingsverband rond het tot stand brengen van een Euregionaal Overzicht onderwijs-arbeidsmarkt.

\subsection{De uitvoering van het projectplan in hoofdlijnen}

\section{Opbouw netwerk: herfst 1995}

Het project is gestart vanuit de in het projectplan verwoorde idee van een 'breed' en 'smal' netwerk. Het smalle netwerk zou de instellingen betreffen waarmee het ROA actief zou samenwerken bij de ontwikkeling van onderdelen van het informatiesysteem; het brede netwerk zou daarenboven de instellingen omvatten met een meer passieve betrokkenheid bij het systeem. Vanuit die gedachte werd in augustus 1995 het projectplan op brede schaal verspreid binnen de Euregio. Doel was in de daarop volgende maanden systematisch contact te leggen met een zo groot mogelijk aantal van deze organisaties, te beginnen echter met de potentiële partners in het smalle netwerk. Daarbij leefde de gedachte in ieder Euregiodeel een 'voortrekker te zoeken, die als centraal punt zou kunnen fungeren voor de deelnemers in het bredere netwerk binnen dat Euregiodeel.

In september werd daarom begonnen met het leggen van contact met enige organisaties waarmee al contact was geweest in het kader van de verkennende studie: in de Regio Aachen het Arbeitsamt en de 'Regio Aachen' (de bestuurlijke partner in de Stichting Euregio Maas-Rijn), in Belgisch Limburg de Gewestelijke Ontwikkelingsmaatschappij GOM en het Arbeidsmarktobservatorium en in Nederlands Limburg het RDC en het RBA ${ }^{2}$. Met organisaties in de provincie Liège waren in de fase van de verkennende studie nog geen contacten geweest. De uitkomsten van deze contacten waren zeer in het kort:

Duitsland

* Arbeitsamt Aachen: heeft in oktober schriftelijk laten weten bereid te zijn tot levering van de beschikbare gegevens, maar geen kans te zien tot actieve medewerking. Dit was

2. Voor nadere informatie over deze organisaties zie het rapport van de verkennende studie, $U$. Teunis, Informatiesysteem onderwijs-arbeidsmarkt voor de Euregio Maas-Rijn, ROA-R-1995/2, Maastricht, 1995. 
overeenkomstig de opstelling die naar voren kwam in het kader van de verkennende studie.

* Regio Aachen: alleen telefonisch contact. Net als in de fase van de verkennende studie bleek er geen mogelijkheid te zijn tot actieve medewerking.

\section{Belgisch Limburg}

* Gewestelijke Ontwikkelings Maatschappij: in september vond een gesprek plaats te Hasselt. De GOM bleek opnieuw zeer in het Euregionale informatiesysteem geïnteresseerd te zijn, maar zag geen kans de rol van voortrekker binnen Belgisch Limburg op zich te nemen. Overwegingen waren de beperkte menskracht, het gegeven dat een deel van de eigen middelen uit Europese fondsen komt (waardoor medefinanciering in het kader van INTERREG-II was uitgesloten) en de start van het project Arbeidsmarktobservatorium, ondergebracht bij het VDAB. Dit project werd als een meer voor de hand liggend aanspreekpunt aangemerkt.

* Arbeidsmarktobservatorium: dit is een projectvan het sociaal Tewerkstellings Comitée (STC), organisatorisch ondergebracht bij het VDAB te Genk. In september vond een gesprek plaats met de projectmanager, de heer Martens. Het project was toen nog in de planfase. Uitgangspunt van het plan was een systematische waarneming van de arbeidsmarkt, vooral ter ondersteuning van het scholingsbeleid. Voorgenomen onderdelen waren de regelmatige verzameling van gegevens, analyse van knelpuntberoepen en screening van doelgroepen. In het gesprek werd vastgesteld dat er grote overeenkomsten waren tussen de voornemens voor het arbeidsmarktobservatorium en het Euregionaal informatiesysteem. Er bleek bereidheid tot samenwerking bij de verdere ontwikkeling van het Euregionaal Overzicht.

\section{Zuid-Limburg}

* RDC-Limburg: ook hier vond in september een gesprek plaats. Hierbij ging het alleen om het deelproject onderwijs, in het bijzonder de ontwikkeling van een Euregionaal Overzicht opleidingen. In eerder contact was reeds gebleken dat dit deelproject raakvlakken had met een aantal RDC-activiteiten. In het gesprek werden deze geïnventariseerd. Naast reguliere RDC-activiteiten (documentatiecentrum) betrof dit een opdracht van de Stichting Euregio Maas-Rijn tot het opstellen van een overzicht van beroepsspecifieke opleidingen in de Euregio. Uitkomst van het gesprek was in grote lijnen dat de bij het RDCLimburg opgebouwde documentatie en de afspraken tot wederzijdse informatievoorziening met het Arbeitsamt (Regio Aachen) en de PMS-centra (Belgisch Limburg, Liège) in grote mate konden voorzien in de behoeften aan informatie over onderwijsvoorzieningen en opleidingsmogelijkheden inde Euregio. Het gesprek vond echter plaats op een moment dat de toekomst van deze activiteiten, als gevolg van het faillissement van het RDC-Limburg, hoogst onzeker was. Afgesproken werd elkaar wederzijds te informeren en het gesprek over samenwerking voort te zetten zodra er meer duidelijkheid zou zijn over de toekomst van deze activiteiten.

* RBA Zuid-Limburg: ook hier vond in september een gesprek plaats. Dit stond mede in het licht van de relatie tussen het Euregio-project en andere activiteiten van het ROA en de 
relatie tot het EURES-CROSSBORDER project binnen de Euregio. Het bleek, evenals eerder in het kader van de verkennende studie werd geconstateerd, dat het RBA geen personele en financiële ruimte had voor directe betrokkenheid bij het project. Resultaat was wel dat de voorzitter van het RBA, tevens projectmanager EURES-CROSSBORDER, dr. L.L.M. Frederix, het project onder de aandacht bracht van het EURES-netwerk. Dit heeft geresulteerd in een presentatie van de projectvoornemens binnen de stuurgroep EURES in mei 1996.

Contact van iets andere aard vond plaats met de werkgroepen van de Stichting Euregio Maas-Rijn. In de fase van de verkennende studie had reeds contact plaatsgevonden met de secretaris van de werkgroep Algemene Beroepsopleiding en Volwasseneneducatie, de heer Richter. Deze was ook behulpzaam bij de brede verspreiding van het rapport en het projectplan door de beschikbaarstelling van adreslijsten. In september vond een presentatie van het project plaats in de vergadering van genoemde werkgroep. Doel van de kant van het ROA was hierbij vooral de weg te banen voor een verdere uitbouw van het netwerk.

Tevens is contact gelegd met de werkgroep Economie. Ook deze stelde het adressenbestand ter beschikking voor verspreiding van het rapport en het projectplan. In januari 1996 heeft een presentatie in deze werkgroep plaatsgevonden. Bij deze gelegenheid werd een contact gelegd met de voorzitter van de werkgroep, de heer Nelles (FOREM St. Vith), dat voor de voortgang van het project erg belangrijk is geweest.

\section{Heroriëntatie van het project}

Eind 1995 vond een nadere overweging plaats van de relatie van dit project tot andere activiteiten van het ROA. Het ging daarbij vooral om het project 'sectorverkenningen' in opdracht van RBA Zuid-Limburg ${ }^{3}$. In het kader van dit project vond reeds een ontsluiting van data met betrekking tot de arbeidsmarkt op subregionaal niveau plaats, verwant aan de data waarop gedoeld wordt in het deelproject 'aanwezige gegevens en publicaties'. Ook werd in het kader van deze sectorverkenningen een systeem van deskundigenbevraging ontwikkeld (in dit geval: arbeidsmarktconsulenten van de Arbeidsvoorzieningsorgansatie) dat verwantschap had met het deelproject 'kwalitatieve signalementen'. De uitkomsten van dit project konden dus niet los worden gezien van de ontwikkeling van het Euregionaal informatiesysteem voor wat betreft Zuid-Limburg.

Bovendien had de fase van betrekkelijk intensief zoeken naar contacten met het oog op het 'smalle' en het 'brede' netwerk, zoals hierboven reeds werd aangegeven, weinig opgeleverd. Wat betreft het smalle netwerk was er de facto niet meer dan de afspraak tot samenwerking met het Arbeidsmarktobservatorium. Wat betreft het brede netwerk bleek opnieuw veel passieve belangstelling bij de reeds eerder benaderde instellingen, maar een werkelijke

3. Zie o.a. J. Horbeek en A. de Grip, Sectorverkenning arbeidsmarkt Zuid-Limburg: de metaal en elektrotechnische industrie, ROA-R-1996/11, Maastricht, 1996. 
uitbreiding van dit netwerk kwam niet tot stand; van spontane respons vanuit de schriftelijk benaderde instellingen was geen sprake.

In januari en februari 1996 heeft binnen het ROA een heroverweging plaatsgevonden van de opzet van het project zoals verwoord in het projectplan. Daaraan lag een analyse ten grondslag van de mogelijke oorzaken van de tegenvallende respons op het project. Naar voren kwamen:

* De belanghebbende instellingen binnen de Euregio zijn overwegend publieke diensten met weinig vrij besteedbare middelen; zij kunnen dus niet makkelijk op een nieuwe activiteit instappen. Er zijn ook veel bureaucratische barrières te nemen.

* De Euregio is voor de betrokken organisaties relatief nog niet van groot belang: de omvang van de activiteiten van de instellingen die op origineel niveau worden uitgevoerd is ten opzichte van de reguliere werkzaamheden op nationaal niveau veelal nog van geringe betekenis. Wel is er bij diverse instellingen de verwachting dat het relatieve belang zal toenemen. Dat betekent veel belangstelling maar nog weinig concrete inzet.

* Het Euregionaal Overzicht was tot dan toe nog slechts een idee, beschreven in globale en kwalitatieve termen. De belangstellenden kunnen zich geen voorstelling maken van wat op dit punt de concrete mogelijkheden zijn.

* Het opbouwen en onderhouden van een breed netwerk vergt veel werk van deels bestuurlijke aard.

Op grond van deze overwegingen werd tot een koerswijziging besloten. Het Euregionaal Overzicht onderwijs - arbeidsmarkt op basis van aanwezige gegevens en publicaties (deelproject 1) werd als kernproject aangewezen. De nadruk werd gelegd op het produceren van een eerste versie van dit Euregionaal Overzicht binnen de looptijd van het project, vanuit de verwachting dat een concreet product de grondslag kan vormen voor een toenemende participatie van de betrokken instellingen. Het verwerven van een INTERREG-II - subsidie op basis van medefinanciering werd daarmee als projectdoel losgelaten. Er zou zo spoedig mogelijk een 'outline' van het Overzicht moeten worden opgesteld, zodat belangstellenden zich een beter beeld van het beoogd product en het daaraan verbonden werk zouden kunnen vormen. Voorts werd besloten de nadruk te leggen op het opbouwen van actieve samenwerking met een beperkt aantal instellingen, gericht op het leveren van een concrete eigen bijdrage aan het Euregionaal Overzicht. Gestreefd zou worden naar ten minste één samenwerkingspartner per Euregiodeel. Dit zou één van de belanghebbende partijen kunnen zijn, maar bij voorbeeld ook een onderzoeksinstelling met verwante taken als het ROA.

De ontwikkeling van kwalitatieve signalementen (deelproject 2) zou niet meer als afzonderlijke activiteit worden gezien. Kwalitatieve elementen zouden voorzover mogelijk deel moeten uitmaken van het Euregionaal Overzicht, dus opgenomen moeten worden in de 'outline', Het ging daarbij om elementen die zouden kunnen worden geproduceerd op basis van bestaande activiteiten van de samenwerkingspartners. 
Wat betreft deelproject 3 betreffende het onderwijs werd besloten de opbouw van informatie over het Euregionaal onderwijs- en opleidingenaanbod stop te zetten tot meer duidelijkheid zou zijn ontstaan over de voortzetting van de RDC-activiteiten op dit terrein en over de publicatie van het reeds door het RDC opgestelde overzicht van opleidingen. Deze publicatie berustte in concept bij de werkgroep 'algemeen beroepsonderwijs en volwasseneneducatie' van de Stichting Euregio Maas-Rijn. Het leggen van contacten met scholen als leveranciers van gegevens en belanghebbenden bij het Euregionaal Overzicht zou wel worden opgepakt, voorzover het overige project hier ruimte voor zou laten.

Deelproject 4 tot slot, coördinatie en continuïteit, werd niet meer als afzonderlijke activiteit gezien maar als deel van de kernstrategie, gericht op actieve samenwerking en het opleveren van een concreet product als grondslag voor continuïteit.

\section{Outline, initiatiefgroep}

De gewijzigde strategie heeft, voorzover tot nu toe valt waar te nemen, goed gewerkt voorzover het gaat om het tot stand brengen van het Euregionaal Overzicht. In februari 1996 kwam de 'outline' in concept gereed ten behoeve van overleg met geïnteresseerden (zie hieronder). De definitieve versie is vertaald in het Duits en het Frans, zodat geïnteresseerden in Duitsland, de Deutschsprachige Gemeinschaft Belgien en de provincie Liège makkelijker konden worden benaderd. Bij het uitwerken van deze 'outline' kon gebruik worden gemaakt van de uitkomsten van het ROA-project 'international labour Market Indicators' ${ }^{4}$ en van de werkzaamheden rond het eerder genoemde project sectorverkenningen Zuid-Limburg. De 'outline' werd opgezet als een gesystematiseerde lijst van globaal omschreven indicatoren met telkens een toelichting met betrekking tot de doelen, werkwijzen, definities en vereiste gegevensbronnen. Gekozen werd voor een pragmatische aanpak, met de nadruk op bijdragen vanuit de verschillende Euregiodelen; daarbij werd de nadruk gelegd op een goede vulling per Euregiodeel, niet op volledige vergelijkbaarheid van alle cijfers.

Met de 'outline' in de hand werd vervolgens contact gelegd met potentiële samenwerkingspartners. Als eerste vond in februari een gesprek plaats met een vertegenwoordiging van FOREM binnen de Deutschsprachige Gemeinschaft. Het contact hiermee was al eerder gelegd via de voorzitter van de werkgroep Economie van de Stichting Euregio, de heer Nelles. Binnen FOREM bleek, in samenwerking met enige andere organisaties, reeds enige jaren een 'Arbeitsmarkt Beobachtungsstelle' (ABEO) te functioneren, waarvan de doelstelling grote overeenkomsten bleek te hebben met het beoogde Euregionaal Overzicht, vooral waar het gaat om het gebruik van reeds aanwezig statistisch materiaal. Er bleek grote belangstelling voor samenwerking bij de ontwikkeling van het Euregionaal Overzicht, voorzover hieraan op basis van het aanwezige materiaal in ABEO een bijdrage zou kunnen

4. U. Teunis, A. de Grip, International Labour Market Indicators: a Proposal for Development, ROAR-1996/2E, Maastricht, 1996. 
worden geleverd. Aan deze bijdrage werden verder geen voorwaarden verbonden. Deze open en coöperatieve opstelling is erg stimulerend geweest voor de voortgang van het project.

Mede op basis van suggesties van de heer Nelles zijn in de daarop volgende maanden contacten gelegd binnen de provincie Liège. Het voornaamste probleem is hier het ontbreken van een instelling vergelijkbaar met de Arbeitsmarkt Beobachtungsstelle of het arbeidsmarktobservatorium, die als 'natuurlijke' partner binnen het project zou kunnen fungeren. Eén van de oorzaken hiervan is dat de provincies als bestuurlijke eenheid binnen het Belgische staatsbestel slechts een beperkte rol spelen. Voor wat betreft de arbeidsvoorziening is het arrondissement de bestuurlijke eenheid. Daarvan zijn er vier in de provincie Liège: Liège, Huy, Waremme en Verviers. Voor wat betreft FOREM zijn twee hiervan samengevoegd, zodat er drie subregionale directies zijn. Binnen het arrondissement Verviers vormt de Duitstalige gemeenschap nog weer een semi-autonome eenheid. Er is geen organisatie die systematisch arbeidsmarktgegevens op provinciaal niveau verzamelt. Ook in de nationale statistieken is betrekkelijk weinig informatie op provinciaal niveau beschikbaar.

In eerste instantie is contact gelegd met het 'Observatoire de l'emploi de Liège'. Dit is een kleine organisatie, organisatorisch gelieerd aan de Universiteit van Liège, die zich bezighoudt met de ontwikkeling van de arbeidsvraag in verband met veranderingen in technologie en economische structuur en de daaruit resulterende kwalificatiebehoefte. Deze organisatie heeft echter in een later stadium laten weten qua schaal en taakstelling niet aan het project te kunnen deelnemen.

Wel is samenwerking tot stand gekomen met FOREM Liège. Hier bleek bereidheid tot een bijdrage op basis van de binnen de arbeidsvoorzieningsorganisatie aanwezige gegevens, dus vooral die betreffende vraag en aanbod van arbeid, en tot aggregatie van deze gegevens vanuit de drie subregionale directies binnen de provincie.

Langs heel andere weg verliep de opbouw van contacten in het Duitse Euregiodeel, Regio Aachen. Reeds in de fase van de verkennende studie was gebleken dat het erg moeilijk zou zijn hier een actieve samenwerkingspartner te vinden. Belangrijke oorzaken zijn hier dat de Regio Aachen als zodanig geen bestuurlijke eenheid is, meerdere Arbeitsamtbezirke omvat en dat de benaderde instanties binnen hun reguliere taakstelling geen mogelijkheid tot een actieve bijdrage zagen.

Vanuit de gedachte dat de partner in een Euregiodeel ook een onderzoeksinstelling kan zijn en niet koste wat kost binnen het Euregiodeel zelf gevestigd hoeft te zijn is contact opgenomen met het Institut für Arbeitsmarkt- und Berufsforschung (IAB) te Nürnberg. Dit is een groot onderzoeksinstituut verbonden aan het Bundesanstalt für Arbeit. Het IAB heeft de afgelopen jaren een groot project REGARIS uitgevoerd, gericht op het ontsluiten van statistisch materiaal op regionaal niveau (de Kreis) met het oog op ondersteuning en evaluatie van regionaal economisch- en arbeidsmarktbeleid. Technisch is het mogelijk een 
aanzienlijk deel van het Euregionaal Overzicht v.w.b, Regio Aachen vanuit REGARIS te vullen. Vanuit het IAB bleek in eerste instantie belangstelling voor actieve deelname aan het project. Bij nader contact werd verwezen naar het Landesarbeitsamt te Düsseldorf, als regionale participant aan REGARIS die een actieve bijdrage zou kunnen leveren. Binnen het Landesarbeitsamt functioneert een kleine onderzoekseenheid die inderdaad bereid bleek een actieve bijdrage te leveren.

Vanuit het streven de groeiende samenwerking zo snel mogelijk te consolideren heeft het ROA de geïnteresseerde partners uitgenodigd voor een vergadering op 24 april 1996 te Maastricht. Aan deze vergadering hebben-de meeste beoogde partners deelgenomen. $\mathrm{Na}$ een presentatie van de verschillende instituten en projecten zijn de voorgestelde opzet van het Euregionaal Overzicht (De 'outline', zie boven) en de verdere werkwijze besproken. Het resultaat van deze vergadering was uiterst positief. Besloten werd tot een enigszins geformaliseerde voortzetting van de samenwerking in de vorm van een 'initiatiefgroep', overigens nadrukkelijk gedacht als een netwerk, open voor iedere organisatie die een actieve bijdrage aan het Euregionaal Overzicht wil leveren. ledere partner binnen de initiatiefgroep zou in principe een bijdrage leveren voor wat betreft het eigen Euregiodeel, zij het beperkt tot de mogelijkheden, in het bijzonder de beschikbare gegevens, van de eigen organisatie. Het ROA zou eventueel aanvullende gegevens kunnen leveren. Afgesproken werd tot slot dat het ROA nog met iedere partner afzonderlijk overleg zou hebben over de precieze bijdrage. Gestreefd zou worden een eerste versie van het Euregionaal Overzicht eind augustus in concept gereed te hebben.

\section{Naar het eerste concept-overzicht}

In de periode na de constituerende vergadering in april heeft met alle partners afzonderlijk een uitvoerige bespreking plaatsgevonden. Voor wat betreft het Landesarbeitsamt was dit tevens het eerste overleg na eerder telefonisch en schriftelijk contact. In essentie is steeds besproken wat de partner zelf zou kunnen leveren en welke gegevens aanvullend door het ROA zouden moeten worden verzameld. De uitkomsten waren per partner zeer verschillend. De Arbeitsmarktbeobachtungsstelle en het arbeidsmarktobservatorium zegden een betrekkelijk volledige bijdrage toe. De voorgenomen bijdragen van FOREM Liège en Landesarbeitsamt zouden zich in hoofdlijn beperken tot data die deze instellingen ambtshalve reeds verzamelen. Hier bleek aanvullende dataverzameling door het ROA van meet af aan noodzakelijk.

Uiteindelijk is voor alle Euregiodelen aanvullende dataverzameling door het ROA uitgevoerd, zij het in verschillende omvang en intensiteit. Voor wat betreft Regio Aachen zijn de meeste aanvullende data betrokken van het Statistisches Landesamt te Düsseldorf en het Statistisches Bundesamt te Wiesbaden. Voor wat betreft zowel Liège als (Belgisch) Limburg is het Steunpunt WAV te Leuven zeer behulpzaam geweest. Het Steunpunt heeft het systeem van dataverzameling ten behoeve van het arbeidsmarktobservatorium ontwikkeld. 
In het verlengde hiervan is ondersteuning geboden bij het raadplegen van diverse Belgische databestanden.

Het is uiteindelijk niet gelukt een eerste versie van het Euregionaal Overzicht eind augustus gereed te hebben. Vertraagde indiening van diverse bijdragen en de onvoorziene omvang van de aanvullende dataverzameling en -bewerking door het ROA waren hier debet aan. In september kon een eerste concept aan de partners in de initiatiefgroep worden gezonden. Dit bevatte een toelichtende tekst in de drie Euregio-talen en een verzameling indicatoren in het Nederlands. Enige van de voorziene indicatoren konden voor geen enkel Euregiodeel worden ingevuld. Verder ontbrak in ieder Euregiodeel een aantal indicatoren en konden andere niet volledig worden ingevuld. Het overgrote deel van de voorziene indicatoren was echter ingevuld met de meest recent beschikbare data.

Op 25 september vond een tweede vergadering van de Initiatiefgroep plaats. Hier werd het concept van de eerste versie van het Euregionaal Overzicht besproken. Ook kwam de voortzetting van het initiatief na de publicatie van de eerste versie aan de orde. Het concept ontmoette weinig bezwaren. Wel werd aangedrongen op interpretatieve toelichting bij en vergelijkende analyse van de, in het concept 'kaal' gepresenteerde, indicatoren. Over de aanvulling van de nog ontbrekende indicatoren, voorzover nog mogelijk, en de opstelling van de interpretatieve en vergelijkende teksten werden procedurele afspraken gemaakt. Alle samenwerkingspartners zouden trachten nog enige aanvullingen aan te leveren in de eerste helft van oktober. Ook zouden allen een aanzet leveren tot interpretatie van de cijfers voor wat betreft hun Euregiodeel, op basis waarvan het ROA een tekst met ook vergelijkende elementen zou opstellen. Afgesproken werd te streven naar publicatie van de eerste versie eind november 1996.

Wat betreft de voortzetting van het initiatief: alle partners onderschreven het belang van een jaarlijkse publicatie van het Euregionaal Overzicht; allen waren ook bereid hier een verdere bijdrage aan te leveren. Daarbij werd uitgegaan van voortzetting van de samenwerkingsconstructie, waarbij iedere partner onder eigen verantwoordelijkheid en voor eigen rekening een bijdrage levert in aansluiting op de eigen taakstelling. Deze taakstelling, en de daaruit voortvloeiende beschikbaarheid van data, stelt grenzen aan de mogelijke bijdrage; dit geldt vooral voor FOREM Liège en het Landesarbeitsamt. Verder werd ingegaan op de organisatorische inbedding van het initiatief. Hierover konden geen besluiten worden genomen, vooral in verband met een voorstel van het ROA tot het verwerven van een EURES-subsidie voor de te maken 'overhead-kosten' (coördinatie, aanvullende dataverzameling en -bewerking, publicatie enz bij het opstellen van een tweede versie van het Euregionaal Overzicht, waarover op dat moment nog geen besluit was gevallen (zie verder par. 1.3 bij deelproject 4). Afgesproken werd hierop terug te komen in een vergadering in het voorjaar van 1997; een vergadering die tevens de start zou moeten vormen voor de productie van de tweede versie van het Euregionaal Overzicht. 
Met enige vertraging is de eerste versie van het Euregionaal Overzicht half december naar de drukker gegaan. Het rapport vermeldt alle participerende instituten (STC-Arbeidsmarktobservatorium Genk, Arbeitsmarktbeobachtungsstelle Ostbelgien St. Vith, FOREM Liège, Landes Arbeitsamt NRW Düsseldorf, Researchcentrum voor Onderwijs en Arbeidsmarkt Maastricht) op de titelpagina. Het rapport is gepubliceerd in de rapportenreeks van het ROA en tevens voorzien van het vignet van de Stichting Euregio. Het was voor de participerende organisaties (vooralsnog) niet mogelijk het rapport integraal te vertalen en in de drie Euregio talen - Duits, Frans en Nederlands - te publiceren. Wel heeft het ROA zorg voor gedragen dat het inleidende hoofdstuk, alsmede het resumé van de belangrijkste uitkomsten in alle drie talen in het rapport op te nemen. Alle gepresenteerde tabellen en grafieken zijn alleen in het Nederlands gepubliceerd. In januari 1997 zal het rapport officieel worden gepubliceerd.

\section{Uitkomsten in hoofdlijnen}

In dit hoofdstuk worden in het kort, deels het voorgaande recapitulerend, de uitkomsten van het project beschreven. Dit geschiedt aan de hand van de vier deelprojecten die in het projectplan van augustus 1995 werden onderscheiden. Waar relevant wordt beknopt op de oorzaken van het slagen of falen van de betreffende deelprojecten ingegaan.

Deelproject 1: Ontwikkeling Euregionaal Overzicht ondenwijs - arbeidsmarkt op basis van aanwezige gegevens en publicaties

Dit is zondermeer het meest succesvolle deelproject gebleken. Het is mogelijk gebleken de meeste van de in de 'outline' voorziene indicatoren daadwerkelijk te vullen, in bepaalde gevallen zelfs met een grotere informatie-rijkdom dan voorzien. Een aantal indicatoren kon uiteindelijk niet voor alle Euregiodelen worden gevuld, enige in het geheel niet. Met name voor Duitsland en België bleek het moeilijk gegevens te verkrijgen over de beroepsbevolking naar sector en beroep. De met de Nederlandse Enquête Beroepsbevolking (EBB) vergelijkbare onderzoeken laten hier op het betreffende regionale niveau geen of weinig uitspraken toe, en alternatieve gegevensbronnen zijn niet steeds aanwezig. Ook arbeidsmarktprognoses en gegevens over de bestemming van abituriënten op de arbeidsmarkt konden niet voor Belgische en Duitse Euregiodelen worden geleverd. Gegevens over onder meer de grensoverschrijdende pendel, grensoverschrijdende onderwijsactiviteiten en grensoverschrijdende bemiddeling bleken (nog) voor geen enkel Euregiodeel beschikbaar. Voor een overzicht van de voorgestelde indicatorenstructuur, de gevulde indicatoren en een toelichting daarbij zij verwezen naar het Euregionaal Overzicht ${ }^{5}$.

5. Overzicht onderwijs-arbeidsmarkt Euregio Maas-Rijn 1996, Arbeidsmarktobservatorium Genk, Arbeitsmarkt Beobachtungsstelle, St. Vith, FOREM, Liège, Landes Arbeitsamt NRW, Düsseldorf, Researchcentrum voor Onderwijs en Arbeidsmarkt, ROA-R-1996/13, Maastricht, 1996. 
Er zijn enige oorzaken aan te wijzen voor het naar verhouding grote succes van dit deelproject:

1. Dit onderdeel sloot het beste aan bij eerder door het ROA uitgevoerde verkenningen op het terrein van de Euregio ${ }^{6}$, andere projecten betreffende de (Zuid-)Limburgse arbeidsmarkt, het project International Labour Market Indicators en de verkennende studie. Een globaal beeld van de beschikbare gegevensbronnen in Duitsland en België en van de ter zake relevante organisaties was bij de aanvang van het deelproject reeds aanwezig. Wat betreft Zuid-Limburg kon direct op reeds opgebouwde bestanden en toegang tot de bestanden van het RBA worden voortgebouwd.

2. Dit deelproject sloot ook het beste aan op de verwachtingen en mogelijkheden van de samenwerkingspartners. Deze hebben allen reeds in enige vorm en omvang een voorziening voor de verwerking van relevante gegevens. Twee van de partners, de Arbeitsmarktbeobachtungsstelle en het arbeidsmarktobservatorium, zijn zelfs mede met dit oogmerk in het leven geroepen. Ook sluit het resultaat, een aantal indicatoren die algemeen als relevant voor aspecten van de arbeidsmarkt en de aansluiting onderwijs arbeidsmarkt wordt gezien, goed aan bij de eigen behoeften van de organisaties. Hier kon snel een resultaat worden geleverd dat zichzelf op 'face-validity' bewijst,

3. De samenwerkingspartners konden hier een bijdrage leveren zonder bijzondere ingrepen in hun organisatie en taakstelling. Hoewel een aantal medewerkers wel bewerkingen op gegevensbestanden heeft uitgevoerd die anders niet uitgevoerd zouden zijn, pasten alle werkzaamheden toch binnen hun normale taakstelling. Op die basis kon ook zonder afzonderlijke financiering worden gewerkt.

Het bovenstaande neemt niet weg dat het slagen van dit deelproject alleen mogelijk was door een inzet vanuit het ROA die veel omvangrijker was dan voorzien. Zowel het publicatieklaar maken van door de partners aangereikte indicatoren als de bewerking van meer of minder ruwe bestanden om ontbrekende onderdelen aan te vullen hebben veel meer tijd gevergd dan voorzien. Dat geldt ook voor de logistiek rond vertaling en publicatieklaar maken van het Euregionaal Overzicht als geheel.

\section{Deelproject 2: Ontwikkeling onderdeel kwalitatieve signalementen}

Zoals in voorgaande paragraaf vermeld is bij de heroriëntatie van het project besloten dit deelproject niet afzonderlijk voort te zetten maar ernaar te streven aanwezige kwalitatieve signalementen op te nemen in een indicator binnen het Euregionaal Overzicht. Dit onderdeel is niet succesvol gebleken: de betreffende indicator is in de eerste versie van het Euregionaal Overzicht nog niet ingevuld. Oorzaken zijn ten eerste dat de projecten, waarvan een kwalitatieve bijdrage werd verwacht, deze verwachting nog niet waar konden maken en ten tweede dat buiten deze projecten geen voorbeelden van kwalitatieve signalementen

6. J.W. van Dam en A. de Grip, De Euregionale arbeidsmarkt: van fictie naar werkelijkheid, ROAR-1991/10, Maastricht, 1991 en J.W. van Dam, A. de Grip en J.A.M. Heijke, Naar een Euregionale arbeidsmarkt Maas-Rijn, Economisch Statistische Berichten, 77 (1992) 3853, pp. 321-324. 
werden aangetroffen. Wat de eerste oorzaak betreft: het ging hier om het door het ROA ten behoeve van het RBA uitgevoerde project sectorale verkenning, en daarbinnen in het bijzonder om de voorziene consultaties per sector, en om de binnen het arbeidsmarktobservatorium voorziene verkenningen door sectorconsulenten. De sectorale verkenningen zijn door het RBA-Limburg in 1996 niet voortgezet; daarmee ontviel de voorziene bijdrage aan de kwalitatieve signalementen voor het Euregiodeel Zuid-Limburg. Wat betreft het arbeidsmarktobservatorium (Belgisch Limburg) hebben de sectorconsulenten veel meer een gerichte taak op het vlak van het verkennen en oplossen van knelpunten gekregen en de meer algemene waarneming van trends en ontwikkelingen veel minder ingevuld dan op grond van de oorspronkelijke plannen werd verwacht.

\section{Deelproject 3: Betrokkenheid onderwijs, ontwikkeling Euregionaal Overzicht opleidingen}

Binnen dit deelproject zijn twee onderdelen onderscheiden: de betrokkenheid van onderwijsinstellingen bij het Euregionaal Overzicht, zowel actief als gebruiker van het materiaal als passief door het beschikbaar stellen van gegevens, en het Euregionaal Overzicht van opleidingen. Beide onderdelen zijn, door verschillende oorzaken, niet succesvol geweest. Wat betreft de betrokkenheid van onderwijsinstellingen is vooral tijdgebrek de oorzaak. Dit onderdeel zou de actieve benadering van een groot aantal onderwijsinstellingen in drie landen en drie taalgebieden hebben gevergd. Een overkoepelende Euregionale organisatie van onderwijsinstellingen bestaat (nog) niet. Er zijn wel plannen gemaakt om deze benadering althans gedeeltelijk uit te voeren, maar naarmate bleek dat de inzet voor het Euregionaal Overzicht omvangrijker zou moeten zijn dan voorzien heeft dit onderdeel een geringere prioriteit gekregen. Een geheel andere geschiedenis kent het Euregionaal Overzicht van opleidingen. Zoals in voorgaande paragraaf beschreven bleek er een duidelijke overlap tussen dit onderdeel en de activiteiten van het toenmalige RDC-Limburg, met name het documentatiecentrum betreffende onderwijsvoorzieningen in de grensregio's en het te ontwikkelen overzicht van specifieke scholing ten behoeve van de Stichting Euregio Maas-Rijn. In afwachting van duidelijkheid over voortzetting van deze activiteiten door de opvolger van het RDC-Limburg van publicatie van dit overzicht is dit onderdeel vooruitgeschoven. Tussentijds heeft overleg plaatsgevonden met één van de initiatiefnemers van het nieuwe AOB-Limburg. Daarbij ontstond de indruk dat aan deze activiteiten de nodige waarde werd gehecht. In een laat stadium bleek echter dat binnen de beperkte organisatie van AOB-Limburg geen ruimte is om de documentatietaak aangaande onderwijsmogelijkheden binnen de Euregio voort te zetten. Het $A O B$ neemt wel deel aan een initiatief tot een LEONARDO-project, dat deels in deze behoefte zou kunnen voorzien, maar over dit projectvoorstel is nog geen besluit gevallen. Het overzicht van specifieke scholing is tot op heden nog niet gepubliceerd. Op het moment dat dit alles duidelijk werd was voor een aanvullende activiteit in het kader van het Euregioproject geen ruimte meer. 
Bij de heroriëntatie van het project (zie paragraaf 2.2) is besloten dit deelproject vooral ten dienste van de ontwikkeling van het Euregionaal Overzicht uit te werken en daarbij de strategie te veranderen van de opbouw van een netwerk naar de opbouw van een hecht samenwerkingsverband met een beperkt aantal instellingen met een actieve bijdrage aan het project. Deze gewijzigde strategie is in ieder geval voor de ontwikkeling van de eerste versie van het Euregionaal Overzicht succesvol gebleken. Op deze basis kon de initiatiefgroep tot stand komen die de basis vormt voor de eerste versie van het Euregionaal Overzicht. Waarschijnlijk sluit deze werkwijze ook het beste aan bij de expertise van het ROA en de begrote personele inzet voor dit project.

Belangrijk aspect is hier de voorziening in de continuïteit van het Euregionaal Overzicht na afronding van het project. Met de partners in de initiatiefgroep is van meet af aan besproken dat het de bedoeling was het Euregionaal Overzicht als een regelmatig terugkerende publicatie te ontwikkelen. Regelmatige publicatie is essentieel met het oog op de beoogde functies van het Euregionaal Overzicht in de sfeer van ondersteuning van concrete institutionele en bestuurlijke processen. Ook neemt de informatieve waarde sterk toe naarmate op basis van beschikbare tijdreeksen een beeld van enige trends kan worden gegeven. Dit uitgangspunt is door alle partners onderschreven. Over de voortzetting na de eerste versie zijn echter in de ontwikkelingsfase geen afspraken gemaakt. De vraag naar continuïteit, en daarmee naar bestuurlijke consolidering van de samenwerking, is aangehouden tot na de afronding van de eerste versie van het Euregionaal Overzicht.

De ervaringen met de ontwikkeling van de eerste versie hebben het ROA wel tot de conclusie geleid dat enige centrale voorziening noodzakelijk is om het Euregionaal Overzicht als semi-permanente voorziening in stand te houden. Ook indien de partners uit eigen middelen of op grond van onderzoeksactiviteiten die reeds plaatsvonden in de eigen regio een bijdrage blijven leveren voor het eigen Euregiodeel, is financiering van de noodzakelijke overheadkosten vereist, coördinatie, aanvullende gegevensverzameling en -bewerking, vertaalkosten, publicatiekosten e.d (zie hoofdstuk 3). Niet zozeer voor de ontwikkeling en invulling van het Euregionale Overzicht alswel voor deze 'spilfunctie' lijkt enige vorm van afzonderlijke financiering noodzakelijk.

Een opening in deze richting bleek mogelijk in een vergadering van de Stuurgroep van het project EURES-CROSSBORDER IGA II, waar, in vervolg op de presentatie in de Stuurgroep EURES (zie paragraaf 1.2), de eerdergenoemde 'outline' nader besproken is. Hier werd de mogelijkheid van de EURES-subsidie ten behoeve van deze 'spilfunctie' naar voren gebracht. In Augustus 1996 is een voorstel aan de EURES-CROSSBORDER Stuurgroep voorgelegd. In een vergadering in september bleek opnieuw veel belangstelling. Bij deze gelegenheid kwam ook de mogelijkheid naar voren de organisatie van het project meer aan EURES te liëren. December 1996 heeft de Stuurgroep van het EURES CROSSBORDER IGA II project echter laten weten dat zij de aanvraag tot financiële deelname in de verdere 
ontwikkeling van het Euregionaal Overzicht niet zal honoreren. Na publicatie van het rapport zal worden nagegaan of de coördinatiekosten op een andere wijze zouden kunnen worden gefinancierd.

\section{Overdraagbare uitkomsten en conclusies}

In dit slothoofdstuk worden, in aansluiting op de beschrijving van de uitvoering en de uitkomsten van het project in de voorgaande hoofdstukken, enige thema's nader belicht. Hierbij is vooral gekeken naar ervaringen die van belang kunnen zijn voor de voortzetting van het Euregionaal Overzicht Onderwijs - Arbeidsmarkt Euregio Maas-Rijn, maar vooral ook voor de opzet en uitvoering van vergelijkbare projecten in andere Euregio's en vergelijkbare vormen van samenwerking in grensgebieden (bij voorbeeld in het kader van EURES CROSSBORDER projecten). Het gaat hier met andere woorden om het product van het project in termen van leerervaringen. De nadruk ligt daarbij op factoren die bevorderend danwel belemmerend kunnen zijn voor het tot stand brengen van vergelijkbare overzichten in andere Euregio's en grensoverschrijdende samenwerkingsprojecten.

\section{Samenwerkingsconstructies}

Eén van de meest in het oog springende conclusies uit hoofdstuk 3 was dat het betrekkelijk grote succes van het deelproject Euregionaal Overzicht mogelijk is gemaakt door het aangaan van een intensieve maar informele samenwerking met een beperkt aantal partners. Er is gewerkt met een strategie waarbij niet de 'top' van de betrokken organisaties werd aan-gesproken maar functionarissen op middenmanagement- en uitvoerend niveau met functies op (onder meer) het terrein van informatieverzameling en -verwerking. Bij deze contactpersonen kon het beste commitment worden verkregen voor het participeren van hun organisatie. Bovendien kon worden samengewerkt in het verlengde van hun reguliere taakstelling. Daarbij was telkens duidelijk dat een bijdrage aan het Euregionaal Overzicht mede in het belang was van, en ook paste binnen de taakstelling van, de eigen organisatie. Aan de samenwerkingspartners konden geen financiële middelen worden geboden, maar wel een voorwaardenscheppend kader (uitgewerkt indicatorenvoorstel, coördinatie, aanvullende dataverzameling enz.).

Een aantal factoren kunnen worden genoemd voor het relatieve succes van deze constructie, althans voor de eerste versie van het Euregionaal Overzicht:

* $\mathrm{Er}$ is een beroep gedaan op organisaties die werkten aan observatoria met een vergelijkbare opzet en taakstelling als het Euregionaal Overzicht voor hun eigen regio (AMO, $A B E O)$ en/of een taakstelling met betrekking tot de informatievoorziening aangaande de arbeidsmarkt in het kader van uitvoeringsorganisaties (LandesArbeitsamt NRW, FOREM). Bij deze organisaties konden het meest direct zowel de reguliere taakstelling van de betrokken medewerkers als de beschikbare informatie worden aangesproken. Het 
Euregionaal Overzicht kan echter voor een veel breder scala van organisaties een functie hebben (zie ook paragraaf 1.1 van de eerste versie van het Euregionaal Overzicht). Vandaar dat aanvankelijk aan een veel breder netwerk is gedacht. Daarbij zouden echter ook organisaties zijn aangesproken met een minder direct belang bij het Euregionaal Overzicht, met een grotere kans op een geringere inzet en voortijdige beëindiging van de samenwerking.

* De bestuurlijke constructies en de bestuurlijke traditie rond de betrokken typen instellingen zijn in de drie Euregio-landen zeer verschillend. Vooral in België wordt vaak een erg complexe structuur aangetroffen, in Duitsland een wat meer hiërarchische en bureaucratische. Bestuurlijke afspraken vereisen onder die omstandigheden veel tijd. Door direct binnen de organisatie naar samenwerking te zoeken kon deze horde worden omzijld.

* Er diende zich niet onmiddellijk een ander kader aan voor de ontwikkeling van een dergelijk Euregionaal Overzicht, zodat er geen competentiestrijd en concurrentie om middelen konden ontstaan.

* Door geen aanvullende subsidie aan te vragen ontstond geen tijdverlies in verband met de besluit- vormingsprocedures ter zake. Zo kon snel worden geopereerd. Een ander aspect hiervan is dat voor verstrekken van een subsidie uit INTERREG (evenals veel andere Europese fondsen) wordt uitgegaan van medefinanciering tot ten hoogste $50 \%$. De overige middelen dienen door de samenwerkende organisaties te worden opgebracht. Dat betekent eerst altijd een gecompliceerde besluitvorming binnen de samenwerkende organisaties.

Waarschijnlijk is de situatie in andere Euregio's minder gecompliceerd dan die in de Euregio Maas-Rijn. Deze is uniek doordat zij drie landen, drie (niet met de landsgrenzen samenvallende) taalgebieden en binnen de landen nog verschillende bestuurlijke eenheden omvat. Desondanks is aannemelijk dat een vergelijkbarg strategie ook in andere Euregio's en CROSSBORDER-projecten tot succes zou kunnen leiden. Dit succes betreft waarschijnlijk vooral de startfase, het opleveren van een eerste versie. Naarmate het project zich ontwikkelt naar een semi-permanente voorziening zullen vormen van meer geformaliseerde samenwerking noodzakelijk zijn. Daarbij is het echter van groot belang dat de samenwerking niet op basis van in algemene termen geformuleerde voorstellen wordt aangegaan maar op basis van een concreet product en concrete vormen van samenwerking.

Een overdraagbare ervaring zou dus kunnen zijn: eerst met zo min mogelijk bureaucratische rompslomp een concreet 'pilot' product realiseren, daarna pas tijd en energie investeren in een passend kader voor de wat langere termijn. Een aansprekend product 'verkoopt' beter en een bestaande samenwerking wordt makkelijker geformaliseerd.

\section{(Ver)taalproblemen}

Het probleem van de meertaligheid wordt makkelijk onderschat. Dat geldt zeker voor de Euregio Maas-Rijn met drie officiële taalgebieden. Dit probleem is binnen het project aan- 
vankelijk onderschat, vooral omdat binnen de aangesproken organisaties in de Duits- en Franstalige gebieden vaak in eerste instantie contact is geweest met personen die ook Nederlands spreken. Vaak zijn dit degenen die al met de grensoverschrijdende contacten van hun organisatie belast waren. Bij nader contact met andere medewerkers van de organisatie blijkt de taal echter wel degelijk een barrière en is de mogelijkheid mensen in hun eigen taal aan te spreken essentieel voor de voortgang van het project. Door de betrokken onderzoekers is veel tijd en moeite genomen voor communicatie in het Duits en het Frans, mondeling, telefonisch en schriftelijk. Waar het gaat om de binnen de initiatiefgroep verspreide stukken is vertaling niet altijd mogelijk geweest, vanwege de kosten en vooral ook vanwege de tijd die met de uitbesteding van vertalingen is gemoeid. Veel stukken zijn dus in het Nederlands verspreid, waaronder het concept van de eerste versie van de indicatoren. Voor de betrokkenen kan dit een barrière zijn voor actieve participatie.

De 'outline' en het tekstgedeelte van de eerste versie van het Euregionaal Overzicht zijn vertaald door een professioneel vertaalbureau. Voor de inzet van professionele vertalers zijn twee beperkingen: tijd en geld. Een voortdurend beroep op vertalers is alleen denkbaar indien hier tevoren in de begroting rekening mee is gehouden en indien tevoren een ruime doch strakke planning van het productieproces is vastgesteld, waarbij steeds tussen aanlevering van indicatoren en tekstgedeelten en de verspreiding voor bespreking periodes voor vertaling zijn ingelast. Dit is moeilijk in een situatie met meerdere samenwerkingspartners die hun bijdrage 'ertussendoor doen' naast de reguliere werkzaamheden.

Wat betreft andere Euregio's en CROSSBORDER-projecten is de taalsituatie nergens zo gecompliceerd als in de Euregio Maas-Rijn. Het gaat hier steeds slechts om twee talen. Toch lijkt het noodzakelijk van meet af aan rekening te houden met deze problematiek en hier ook met samenwerkingspartners afspraken over te maken. Goede beheersing van beide talen door de direct betrokkenen is essentieel voor het welslagen van dit type projecten.

\section{Regionale indelingen}

Een heel specifiek probleem doet zich in geval van de Euregio Maas - Rijn voor waar het gaat om het niet samenvallen van de grenzen van de Euregiodelen met andere relevante grenzen. Het gaat hier zowel om bestuurlijke grenzen als om in de benodigde databronnen onderscheiden regio's.

Wat betreft de bestuurlijke grenzen: deze problematiek doet zich vooral voor in het Duitse en in mindere mate in het Nederlandse, Euregiodeel. De Belgische Euregiodelen vallen samen met provincies en met de semi-autonome Deutschsprachige Gemeinschaft). Het Duitse Euregiogebied, Regio Aachen, is speciaal voor de deelname in de Euregio Maas-Rijn in het leven geroepen. $\mathrm{Er}$ is geen enkele autoriteit specifiek voor dit gebied aanspreekbaar en er is ook geen enkele bestuurlijke bevoegdheid bij Regio Aachen belegd. Voor zowel de functionaliteit als de productie van het Euregionaal Overzicht essentiële instituties op het 
terrein van onderwijs en arbeidsmarkt vallen qua werkingsgebied niet steeds met Regio Aachen samen. Voor het Euregiogebied Zuid-Limburg geldt grosso modo hetzelfde, zij het dat deze regio-indeling ook buiten het kader van de Euregio diverse functies heeft. Dit gold onder meer voor het voormalige RBA gebied Zuid-Limburg. Door de fusie van de beide RBA's in Limburg is het de vraag in hoeverre deze regio-indeling relevant blijft.

Waar het gaat om de statistische regio-indeling zijn er vergelijkbare, deels uit de bestuurlijke indeling voortvloeiende, problemen. Regio Aachen valt niet precies samen met de Kreisgrenzen; de Kreis is echter voor een aantal noodzakelijke statistieken de relevante eenheid. Het Euregiodeel Zuid-Limburg valt niet precies samen met het COROP-gebied Zuid-Limburg, hetgeen bepaalde statistieken onvolledig maakt. Wat betreft België bleek een probleem dat bepaalde gegevens, vooral die van de arbeidsvoorziening, op het niveau van het arrondissement beschikbaar zijn en dus geaggregeerd moeten worden. De Deutschsprachige Gemeinschaft valt qua indeling niet met één arrondissement samen. Een probleem van een andere orde is dat de provincie in bepaalde statistieken geen relevante eenheid is; andere statistieken zijn alleen op het niveau van het gewest (Wallonië, Vlaanderen) beschikbaar.

Een verwant probleem is dat de Euregiodelen deels niet samenvallen met de door de Europese Unie gehanteerde regio-indeling NUTS 2/3. Dit maakt het gebruik van beschikbare secundaire data van met name EUROSTAT moeilijk. Ook de regioindeling die voor de europese steunprogramma's wordt gebruikt valt niet samen met de indeling van de Euregiodelen, zodat de werking van verwante projecten niet steeds op dezelfde regionale eenheden betrekking heeft.

In hoeverre deze problematiek zich ook in andere Euregio's voordoet is zonder nader onderzoek niet aan te geven. In ieder geval lijkt een overdraagbare ervaring dat bij de start van dit type projecten terdege met zowel de bestuurlijke indelingen als met relevante statistische regio's rekening moet worden gehouden. Zowel de aanspreekbaarheid van relevante autoriteiten als de mogelijkheden voor een efficiënte informatievoorziening met betrekking tot het projectgebied zijn hierbij in het geding.

\section{Bestuurlijk kader, continuïteit}

Hiervoor is reeds ingegaan op de noodzaak van een zekere formalisatie van de samenwerking om een semi-permanente voortzetting van het Euregionaal Overzicht zeker te stellen. Daarbij werd wel de conclusie getrokken dat het in het onderhavige geval voordelig is geweest in de beginfase niet de nadruk op te leggen op de formele structuur op langere termijn. Voor de wat langere termijn lijkt een genormaliseerde structuur echter onontkoombaar. Ten eerste omdat een voortgezette deelname vanuit de samenwerkende organisaties een zeker bestuurlijk draagvlak vereist. Ten tweede, zoals reeds in paragraaf 2.3 vastgesteld, omdat een coördinerende instelling noodzakelijk is die gefinancierd en organisatorisch ingebed moet worden. 
In het eerder genoemde ontwikkelingsproces van informele samenwerking rond een eerste concreet informatieproduct naar een genormaliseerde samenwerking rond een semi-permanente voorziening dient gericht aan de invulling van deze 'spilfunctie' te worden gedacht. Essentieel lijkt dat de 'spil' zich enigszins onafhankelijk van de samenwerkingspartners kan bewegen en, ook door beheersing van de betrokken talen, zelfstandig kan optreden. Dat zou betekenen dat onderbrengen van deze 'spilfunctie' bij een onafhankelijke professionele organisatie, los van de betrokken diensten, instellingen en overheden, waarschijnlijk de voorkeur heeft.

Eisen die aan de 'spilfunctie', c.q. aan deze professionele organisatie, kunnen worden gesteld zijn.

* Voldoende professionele kennis om de dataverzameling door de samenwerkingspartners te coördineren, te stimuleren en waar nodig vlot te trekken;

* Voldoende beheersing van de betrokken talen, in ieder geval voor de dagelijkse mondelinge en schriftelijke communicatie;

* Voldoende secretariële capaciteit om de coördinatiefunctie en de publicatiebegeleiding te verzorgen.

\section{Gegevensbronnen}

De beschikbaarheid van gegevens is niet de grootste belemmerende factor gebleken in het tot stand brengen van een Euregionaal Overzicht. Aan te nemen is dat ook in andere gevallen niet zo zal zijn, mits ook hier de keuze wordt gemaakt om met de 'best beschikbare' gegevens te werken in plaats van met volledig vergelijkbare. Slechts bepaalde typen gegevens, zoals arbeidsmarktprognoses en informatie over de bestemming van abiturienten, zullen in vrijwel alle gevallen een probleem blijken.

Probleem is veeleer de ontsluiting van de aanwezige gegevens. Essentieel is daarbij dat voor een volledig overzicht van onderwijs, arbeidsmarkt en de relaties daartussen gegevensbronnen moeten worden gecombineerd die nooit allemaal binnen één organisatie allen aanwezig zijn en die ook zelden door één persoon worden overzien. De inzet van deskundigheid op het terrein van het ontsluiten van diverse databronnen is dus essentieel voor het welslagen van een dergelijk project. Dat geldt zeker voor de aanvangsfase. In het geval van het Euregionaal Overzicht is naast de inbreng vanuit de samenwerkingspartners ook de inzet van dit type deskundigheid, in casu van vooral ROA en Steunpunt WAV, van doorslaggevende betekenis geweest. Bij de verdere ontwikkeling van het Euregionaal Overzicht zal in toenemende mate de aandacht moeten uitgaan naar het verbeteren van de onderlinge vergelijkbaarheid van de te presenteren indicatoren. Ook op dit punt is inhoudelijke deskundigheid met betrekking tot opleidings-, beroeps- en bedrijfssector classificaties van groot belang. Bovendien versterkt dit punt de noodzaak tot het formaliseren van de samenwerking tussen de betrokken partners in de verschillende Euregiodelen. 
Bij continuering van het Euregionaal Overzicht is het streven de dataverzameling meer door de samenwerkingspartners te doen uitvoeren, op basis van de zoekstrategieën die voor de eerste versie zijn ontwikkeld. Gezien echter de waarschijnlijkheid dat er op dit punt regelmatig problemen zullen optreden, bronnen veranderen en verdere ontwikkelingen mogelijk moeten zijn is het van belang dat rond de 'spilfunctie' voldoende inhoudelijke deskundigheid aanwezig blijft. De ervaring rond de opstelling van de eerste versie is dat een vrij vergaande deskundigheid ten aanzien van de beschikbare bronnen in alle drie betrokken landen kon worden opgebouwd.

\section{(On)afhankelijkheid van andere projecten en producten}

Zoals in hoofdstuk 2 aangegeven is bij de uitvoering van dit project gezocht naar het vermijden van overlap met, c.q. het gebruik maken van de uitkomsten van, andere projecten. In het geval van het deelproject Euregionaal Overzicht is dit succesvol geweest; twee andere deelprojecten. Kwalitatieve signalementen en Euregionaal Overzicht van onderwijsvoorzieningen, konden niet worden gerealiseerd mede doordat ze afhankelijk waren gemaakt van andere projecten en producten die uiteindelijk niet de verwachte bijdrage aan dit project konden leveren. Het betreft hier de, reeds in het voorgaande genoemde, relaties met de beoogde kwalitatieve onderdelen van de sectorale verkenningen voor (zuid-)Limburg en van het Arbeidsmarktobservatorium en met de documentatie over onderwijsvoorzieningen van voorheen - RDC-Limburg. Ook kan in dit verband de vertraging van een beoogd proefproject met schoolverlatersonderzoek in (Belgisch) Limburg worden genoemd, waardoor de betreffende indicator op afzienbare termijn voor slechts één Euregiodeel (Zuid-Limburg) kan worden gevuld. 